\title{
ECONOMIC PERFORMANCES OF AGRICULTURE OF CEFTA AND FORMER CEFTA COUNTRIES ${ }^{1}$
}

\author{
Jelena Birovljev², Danilo Đokic ${ }^{3}$, Bojan Matkovski ${ }^{4}$, Žana Kleut ${ }^{5}$
}

\begin{abstract}
Summary
All CEFTA countries had very similar stages of economic development after World War II. Many of them were centrally-planned socialist economies and the political changes that have occurred in these countries in the late 20th century caused changes in the whole economic system, as well as in the agricultural sector. Aim of this paper is to compare economic performances of agriculture of these countries with former CEFTA countries (Poland, Czech Republic, Slovakia, Hungary, Slovenia, Bulgaria, Romania and Croatia) which joined EU after 2004. The development performances of agriculture are considered according to the production and export performances of this economic sector, using a comparative approach. The results showed that there is a gap in development of agriculture between CEFTA countries and selected EU countries, so performances of agricultural sector are far from $E U$.
\end{abstract}

Key words: Agriculture, Promethee method, Cluster analysis, EU, CEFTA.

JEL: $Q 17, Q 18, F 15$

\section{Introduction}

The economic performance of the agricultural sector is difficult to define precisely and comprehensively. Many authors have considered a variety of indicators to explain this term. Some studies use partial labour productivity, capital productivity and land productivity (Van

1 The paper presents a part of research on the project: SustainableAgriculture and Rural Development in terms of the Republic of Serbia strategic goals implementation within Danube region (III 46006), finances by Ministry of Education, Science and Technological Development of Republic of Serbia.

2 Jelena Birovljev, Phd, Full Professor, University of Novi Sad, Faculty of Economics in Subotica, Segedinsku put 9-11, 24000 Subotica, Serbia, Phone: +38124628066, E-mail: birovljevj@ef.uns.ac.rs

3 Danilo Đokić, MSc, Teaching Assistant, University of Novi Sad, Faculty of Economics in Subotica, Segedinsku put 9-11, 24000 Subotica, Serbia, Phone: +381214852907, E-mail: danilo.djokic@ef.uns.ac.rs

4 Bojan Matkovski, MSc, Teaching Assistant, University of Novi Sad, Faculty of Economics in Subotica, Segedinsku put 9-11, 24000 Subotica, Serbia, Phone: +38124628046, E-mail: bojan.matkovski@ef.uns.ac.rs

5 Žana Kleut, MSc, Teaching Assistant, University of Novi Sad, Faculty of Economics in Subotica, Segedinsku put 9-11, 24000 Subotica, Serbia, Phone: +381214852907, E-mail: zana.kleut@ef.uns.ac.rs 
Passel et al., 2007). In order to evaluate position of Slovakian agriculture in EU (European Union), Szabo and Grznar (2015) used the following indicators - agricultural production for the evaluation of effectiveness, intermediate consumption, fixed assets, labour force, levels of livestock, and supports/subsidies for the rendition of the level of inputs. In their study of the agriculture sector of the Western Balkans, Nikolic et al. (2017) used share of agriculture in total employment, net production index number, balance of agriculture product trade, agricultural gross value added as variables that describe importance of agricultural sector. Usually, unavailability of some data for all observed countries has influence on the selection of variables.

The Central European Free Trade Agreement (CEFTA) is a trade agreement between non-EU countries, members of which are now mostly located in Southeastern Europe. Founded in 1992 by Poland, Czechoslovakia and Hungary, CEFTA has been significantly transformed (Table 1). Its essential purpose, as contained in the founding Treaty signed in Cracow in December 1992 was to liberalize their mutual trade in a timescale which paralleled trade liberalization with the EU (Dangerfield, 2006). Today, members of CEFTA are Serbia, Bosnia and Herzegovina, Montenegro, Macedonia, Albania, Moldova and Kosovo (as UNMIK). Other countries have left CEFTA after their accession to EU.

Table 1. Members of CEFTA

\begin{tabular}{|l|c|l|c|c|}
\hline Members of CEFTA & Joined & Former members of CEFTA & Joined & Left \\
\hline FYR Macedonia & 2006 & Hungary & 1992 & 2004 \\
\hline Serbia & 2007 & Czech Republic & 1992 & 2004 \\
\hline B\&H & 2007 & Slovakia & 1992 & 2004 \\
\hline Albania & 2007 & Poland & 1992 & 2004 \\
\hline Moldova & 2007 & Slovenia & 1996 & 2004 \\
\hline Montenegro & 2007 & Romania & 1997 & 2007 \\
\hline Kosovo (as UNMIK) & 2007 & Bulgaria & 1999 & 2007 \\
\hline & Croatia & 2003 & 2013 \\
\hline
\end{tabular}

Source: CEFTA Portal, 2017

CEFTA is very important for Western Balkan countries. As Kikerova (2009) concluded, in only two years of implementation, the CEFTA agreement achieved noticeable positive effect in the form of significant growth of total trade in goods between these countries. On the other hand, CEFTA has played a modest, but useful role in the EU enlargement process, at no stage was there any serious intention (or possibility) that it would be anything other than an interim arrangement to serve a basic market integration function as a part of EU pre-accession (Dangerfield, 2006). Deeper integration within the CEFTA agreement, in preparation for entry into the EU, is crucial purpose of this agreement, because all countries belonging to CEFTA agreement are in different stages of the EU integration process, with the exception of Moldova (Table 2). 
Table 2. CEFTA countries in process of EU integration

\begin{tabular}{|l|l|c|c|}
\hline Country & Status & Year & Open negotiations \\
\hline FYR Macedonia & Candidate country & 2005 & No \\
\hline Montenegro & Candidate country & 2010 & Yes \\
\hline Serbia & Candidate country & 2012 & Yes \\
\hline Albania & Candidate country & 2014 & No \\
\hline B\&H & Potential candidate & - & No \\
\hline Kosovo (as UNMIK) & Potential candidate & - & No \\
\hline Moldova & - & - & - \\
\hline
\end{tabular}

Source: European Commission, 2017 (ec.europa.eu)

The aim of this paper is identification and comparison of the economic performances of agriculture in current and former CEFTA countries. First, the importance of agriculture in the overall economy will be determined in these countries by the following indicators: the share of agriculture in GDP, the share of agriculture in total employment and the share of agriculture in foreign trade. Then, this paper will provide an answer to the question of difference in economic performances of agriculture of CEFTA countries and former CEFTA countries that became members of EU. Economic performances are observed according to production performances and export performances. Also, the Netherlands, Germany and France are included in analysis as a benchmark due to their overall economic development.

\section{Materials and methods}

Analysis of agricultural performances of CEFTA and selected EU countries is divided in two stages. In the first stage, the goal was to group selected countries by importance of agriculture in their economy. In order to achieve this goal, cluster analysis was performed. Cluster analysis is the modern statistical method of partitioning an observed sample population into relatively homogeneous classes, to produce an operational classification (Stanojević et al., 2017). The objective is to sort observations into groups called clusters so that the degree of statistical association is high among members of the same group and low between members of different groups (Berlage and Terweduwe, 1988). The grouping in cluster analysis was based on the results (scores) calculated according to the characteristic values of all the variables, separately for each observed unit. K-means method was used in this study in order to divide countries in only two groups. The goal of the K-means method is to split the total number of observations into a prearranged number of $\mathrm{k}$ homogenous groups based on preferred characteristics (Lattin et al., 2003). The indicators of the agricultural importance in the economic development were used as variables are:

$\mathrm{X} 1$ - Share of agriculture in GDP (\%);

$\mathrm{X} 2$ - Share of agriculture in total employment (\%);

X3 - Share of agriculture in total export (\%).

In the second stage, the goal was to rank selected countries by economic performances of their agriculture. In order to achieve this goal, the PROMETHEE method was used as 
an adequate method for solving problems whose aim is multi-criteria ranking of final set of alternatives based on a number of criteria which need to be maximized or minimized (Nikolić et al., 2017). For each observed alternative it calculate its value expressed in level of preferences. Thereby, each alternative is evaluated based on the two preference flows. Positive preference flow $\varphi+(\mathrm{P})$ indicate how much is given alternative better than the other (according to all criteria). Accordingly, the higher this preference flow is, the alternative is better. The negative flow of preference $\varphi-(\mathrm{P})$ indicates how much a given alternative is worse than the rest, and therefore if this flow is lower, the alternative is better. After that, the PROMETHEE method accounts net preference flow $\varphi(P)$ as the difference between these two flows (Brans, Mareschal, Vincke, 1984; Brans, Vincke, 1985). The multi-criteria analysis was conducted by using the Visual PROMETHEE software package in order to rank selected countries by their performances of agriculture. Economic performances of agriculture are described by variables given in Table 3 . Variables Y1, Y2, Y3 and Y4 are indicators of production performances, while other variables are indicators of export performances.

Table 3. Indicators of economic performances of agriculture

\begin{tabular}{|c|c|c|c|}
\hline Mark & Variable & Unit & Description \\
\hline$Y_{1}$ & $\begin{array}{l}\text { Structure of resources in } \\
\text { agriculture }\end{array}$ & $\begin{array}{l}\text { ha/active } \\
\text { farmer }\end{array}$ & $\begin{array}{l}\text { Represented by the relationship land/labour. } \\
\text { In the development of agriculture, land/labour } \\
\text { ratio is the dominant factor for selection of } \\
\text { production technology (chemical-biological and/ } \\
\text { or mechanical), i.e. it has a crucial influence on } \\
\text { preferences towards labour-saving or land-saving } \\
\text { technologies. }\end{array}$ \\
\hline $\mathrm{Y}_{2}$ & $\begin{array}{l}\text { Land productivity in } \\
\text { agriculture }\end{array}$ & $\$ /$ ha & $\begin{array}{l}\text { The ratio of value of agricultural products to the } \\
\text { area of agricultural land in use. It can be indicator } \\
\text { of intensification of production. }\end{array}$ \\
\hline $\mathrm{Y}_{3}$ & $\begin{array}{l}\text { Labour productivity in } \\
\text { agriculture }\end{array}$ & $\begin{array}{l}\text { \$/active } \\
\text { farmer }\end{array}$ & $\begin{array}{l}\text { The ratio of value of agricultural products to the } \\
\text { number of active farmers. Higher values indicate } \\
\text { more effective absorption of the labour factor } \\
\text { in agricultural production, and consequently a } \\
\text { higher residual income per unit of agricultural } \\
\text { labour }\end{array}$ \\
\hline $\mathrm{Y}_{4}$ & $\begin{array}{l}\text { Share of livestock production } \\
\text { in total agricultural production }\end{array}$ & $\%$ & $\begin{array}{l}\text { The ratio of value of livestock production to } \\
\text { total agricultural production. Lower level of this } \\
\text { share indicate that agriculture is extensive i.e. the } \\
\text { agricultural structure was dominated mainly by } \\
\text { lower-value, plant-origin products, which were } \\
\text { insufficiently used for conversion into livestock } \\
\text { products with higher added values }\end{array}$ \\
\hline $\mathrm{Y}_{5}$ & $\begin{array}{l}\text { Export of agricultural products } \\
\text { per hectare of agricultural land }\end{array}$ & $\$ /$ ha & $\begin{array}{l}\text { The ratio of export value of agricultural products } \\
\text { to the area of agricultural land in use. This is } \\
\text { indicator of export performances of agriculture. }\end{array}$ \\
\hline $\mathrm{Y}_{6}$ & $\begin{array}{l}\text { Export of agricultural products } \\
\text { per active farmer }\end{array}$ & $\begin{array}{l}\text { \$/active } \\
\text { farmer }\end{array}$ & $\begin{array}{l}\text { The ratio of export value of agricultural products } \\
\text { to import value. Higher values indicate better } \\
\text { export performances of agriculture. }\end{array}$ \\
\hline
\end{tabular}




\begin{tabular}{|c|c|c|l|}
\hline Mark & \multicolumn{1}{|c|}{ Variable } & Unit & \multicolumn{1}{c|}{ Description } \\
\hline $\mathrm{Y}_{7}$ & $\begin{array}{l}\text { The export/import coverage of } \\
\text { the agricultural products }\end{array}$ & $\%$ & $\begin{array}{l}\text { The ratio of export value of agricultural } \\
\text { products to the number of active farmers. Values } \\
\text { above 100\% indicate positive trade balance of } \\
\text { agricultural products. }\end{array}$ \\
\hline
\end{tabular}

Source: Author

The empirical research was based on the data of the Food and Agriculture Organization (FAO), especially the data related to the resources, production and foreign trade of agricultural products in the period 2011-2013. The data of share of agriculture in gross domestic product (GDP) and GDP per capita were taken from World Bank database.

\section{Results and discussion}

Analysis of economic performances of agriculture in CEFTA and former CEFTA countries is divided in two sections. In first, economic relevance of agriculture is observed, while in second production and export performances are analyzed. Table 3 presents the economic relevance of agriculture in the CEFTA countries, as well as a synthetic indicator of socioeconomic development - GDP per capita. According to Nowak and Kaminska (2016), Netherlands, Germany and France are three countries with the highest performances of agricultural sector in EU. Because of that, these countries are included in analysis as a benchmark of the level of agricultural development (Table 4). Beside these countries, the highest level of GDP per capita is recorded in Slovenia (20,729 euro), Czech Republic (17,557 euro), Slovakia (16,089 euro), Poland (12,559 euro) and Hungary (12,366 euro). All of these countries joined EU in 2004.

Table 4. Economic relevance of agriculture in the CEFTA countries (average for period 2011-2013)

\begin{tabular}{|l|c|c|c|c|}
\hline Country & $\begin{array}{c}\text { Share of } \\
\text { agriculture in } \\
\text { GDP (\%) }\end{array}$ & $\begin{array}{c}\text { Share of } \\
\text { agriculture in total } \\
\text { employment (\%) }\end{array}$ & $\begin{array}{c}\text { Share of } \\
\text { agriculture in total } \\
\text { export (\%) }\end{array}$ & $\begin{array}{c}\text { GDP per capita } \\
\text { ( \$ ) }\end{array}$ \\
\hline Netherlands & 1.78 & 2.30 & 13.39 & 44,290 \\
\hline Germany & 0.85 & 1.53 & 5.62 & 41,178 \\
\hline France & 1.76 & 2.97 & 12.55 & 36,353 \\
\hline Slovenia & 2.15 & 8.47 & 5.82 & 20,729 \\
\hline Czech Republic & 2.56 & 3.03 & 4.62 & 17,557 \\
\hline Slovakia & 3.63 & 3.20 & 5.15 & 16,089 \\
\hline Poland & 3.16 & 12.50 & 11.44 & 12,559 \\
\hline Hungary & 4.60 & 4.93 & 8.79 & 12,366 \\
\hline Croatia & 4.51 & 12.53 & 11.34 & 11,593 \\
\hline Romania & 6.26 & 29.43 & 9.23 & 8,981 \\
\hline Bulgaria & 5.29 & 6.63 & 16.31 & 6,994 \\
\hline Montenegro & 9.44 & 5.67 & 15.52 & 6,408 \\
\hline
\end{tabular}




\begin{tabular}{|l|c|c|c|c|}
\hline \multicolumn{1}{|c|}{ Country } & $\begin{array}{c}\text { Share of } \\
\text { agriculture in } \\
\text { GDP (\%) }\end{array}$ & $\begin{array}{c}\text { Share of } \\
\text { agriculture in total } \\
\text { employment (\%) }\end{array}$ & $\begin{array}{c}\text { Share of } \\
\text { agriculture in total } \\
\text { export (\%) }\end{array}$ & $\begin{array}{c}\text { GDP per capita } \\
\text { ( \$ ) }\end{array}$ \\
\hline Serbia & 9.68 & 21.17 & 22.01 & 5,237 \\
\hline FYR Macedonia & 10.97 & 18.23 & 14.98 & 4,853 \\
\hline B\&H & 8.01 & 21.42 & 8.37 & 4,249 \\
\hline Albania & 21.71 & 45.80 & 4.60 & 3,945 \\
\hline Moldova & 14.33 & 27.57 & 41.72 & 1,848 \\
\hline
\end{tabular}

Source: The authors' calculations on the basis of World Bank and FAOstat. 2017

The least developed countries are current members of CEFTA and all of these countries are part of Western Balkan region, except Moldova. The transformation of the agricultural sector in these countries created a gap not only in agricultural development performances between the countries and the EU countries but also in export performances. Although agriculture's share in the economy has decreased since 2000, it is still relatively more important in the CEFTA than in the EU, both in terms of value added and employment. Rule that in the countries with a lower level of the socio-economic development, agriculture is more important for the economy is once more confirmed (Gajic et al., 2015).

Cluster analysis was performed in order to divide these countries in two groups. The analysis refers to the factors that determine the importance of agriculture in the overall economy - the share of agriculture in total employment, the creation of GDP and exports. Results are shown in Table 5. First cluster includes all countries that are members of EU, except Montenegro. In these countries, importance of agriculture in overall economy is at low level.

Table 5. Cluster analysis of agriculture in the CEFTA countries

\begin{tabular}{|l|c|l|c|}
\hline \multicolumn{2}{|c|}{ Cluster 1 } & \multicolumn{2}{c|}{ Cluster 2 } \\
\hline Country & Distance & Country & Distance \\
\hline Netherlands & 2.99 & Romania & 5.57 \\
\hline Germany & 3.89 & Serbia & 4.79 \\
\hline France & 2.43 & FYR Macedonia & 5.35 \\
\hline Slovenia & 3.01 & B\&H & 6.33 \\
\hline Czech Republic & 3.57 & Albania & 14.03 \\
\hline Slovakia & 3.20 & Moldova & 14.45 \\
\hline Poland & 3.96 & & \\
\hline Hungary & 1.05 & & \\
\hline Croatia & 3.99 & & \\
\hline Bulgaria & 3.77 & & \\
\hline Montenegro & 4.62 & & \\
\hline
\end{tabular}

Source: The authors' calculations on the basis of World Bank and FAOstat, 2017 
On the other hand, members of second cluster are Romania, Serbia, FYR Macedonia, Bosnia and Herzegovina, Albania and Moldova. Membership in the EU does not mean that it will necessarily get to the agricultural consolidation and the gradual disappearance of small farms. On the contrary, the number of farms with less than 2 hectares in Romania increased (Hubbard et al., 2014). Beside other factors, this probably slow downed the development of Romanian agriculture and placed it in second cluster.

The multi-criteria analysis was conducted by using the Visual PROMETHEE software package in order to rank selected countries by trade and production performances of agriculture. These performances were described by the variables presented in Table 3 .

In terms of values of the analyzed variables, the individual countries are characterized by a high degree of differentiation. The variation ranges from about $33 \%$ to $275 \%$ (Table $6)$. The greatest diversity of the surveyed units is manifested in the case of variable Y5 export of agricultural products per hectare of agricultural land (\$/ha) and Y6 - export of agricultural products per active farmer (\$/active farmer), both variables being indicators of export performances. This high level of variation could be expected if export performances of Netherlands (48,103 \$/ha and 467,458 \$/farmer) and Albania (80 \$/ha and 145 \$/farmer) are concerned. The smallest variation was seen in case of variable Y4 - share of livestock production in total agricultural production (\%). Interestingly, in period 2004-2014, share of livestock production has declined in most of observed countries, especially CEFTA countries, while Netherlands and Germany still have high level of this share (above 64\%). According to Miklos (2014) the decline of the animal sector has serious consequences for the whole sector in Hungary. Beside economic effects, as the total number of livestock units dropped to less than half of what it was in the mid-1980, the lack of enough natural manure makes it more and more difficult to improve the quality of the soils. According to this, it could be concluded that Hungarian livestock products have not be able to compete with same products from "old" EU countries.

Table 6. Characteristics of the variables describing the production and trade performances of the agricultural sector of the selected countries

\begin{tabular}{|c|c|c|c|c|c|c|c|}
\hline & Y1 & Y2 & Y3 & Y4 & Y5 & Y6 & Y7 \\
\hline Minimum & $\begin{array}{c}1.8 \\
\text { Albania }\end{array}$ & $\begin{array}{c}421 \\
\text { B\&H }\end{array}$ & $\begin{array}{c}1,857 \\
\text { Albania }\end{array}$ & $\begin{array}{c}21 \\
\text { Macedonia }\end{array}$ & $\begin{array}{c}80 \\
\text { Albania }\end{array}$ & $\begin{array}{c}145 \\
\text { Albania }\end{array}$ & $\begin{array}{c}11 \\
\text { Albania }\end{array}$ \\
\hline Maximum & $\begin{array}{c}38.86 \\
\text { Montenegro }\end{array}$ & $\begin{array}{c}7,191 \\
\text { Netherlands }\end{array}$ & $\begin{array}{c}69,778 \\
\text { Netherlands }\end{array}$ & $\begin{array}{c}72 \\
\text { Netherlands }\end{array}$ & $\begin{array}{c}48,103 \\
\text { Netherlands }\end{array}$ & $\begin{array}{c}467,458 \\
\text { Netherlands }\end{array}$ & $\begin{array}{c}187 \\
\text { Serbia }\end{array}$ \\
\hline Average & 17.1 & 1,262 & 19,327 & 43.3 & 4,145 & 55,804 & 97.6 \\
\hline $\begin{array}{c}\text { Standard } \\
\text { Dev. }\end{array}$ & 12.2 & 1,577 & 20,355 & 14.2 & 11,398 & 112,494 & 55.3 \\
\hline
\end{tabular}

Source: The authors' calculations on the basis of World Bank and FAOstat, 2017

On the basis of The PROMETHEE method, the countries were ranked by development performances of their agricultural sector. Table 7 shows the results of the analysis. Net preference flow $(\varphi)$ takes the values from -0.6607 to 0.8125 . The best rated was the 
Netherlands (the value of 0.8125$)$, followed by Germany (0.6864) and France (0.6369). According to this ranking, agricultural sector of these countries is the most developed and therefore taking them as benchmark is justified. Next group are: Hungary, Czech Republic, Slovakia, Slovenia and Poland, the countries that joined EU in 2004. Their net preference flow $\varphi$ is still above zero. Good performance of their agricultural sector is a result of joining the EU. According to Chrastinová and Burianová (2009) the results achieved by Slovak agriculture in 2004-2007 (i.e. after the integration into the EU) suggest that the income within the sector has improved also due to the inflow of the EU subsidies. In spite of good ranking of Czech Republic and Slovakia, they have one common problem connected with export performances. Czech agricultural production covers the domestic consumption by only $60 \%$ to $70 \%$ in the case of Slovakia, the situation is even worse, as the domestic production covers the local consumption by only a little more than $40 \%$ (Bielik et al., 2013).

Experience of other new EU member states from Central and Eastern Europe shows that price, production and trade can significantly change after accession, as well as during the pre-accession period. The extent of this adjustment occurring before or after accession depends on the pre-accession policy and market adjustments. Crucial tasks for these countries during the accession process are finding niche markets or being cost competitive (Mizik and Meyers, 2013).

Table 7. The classification of the selected countries in terms of trade and production performances of agriculture

\begin{tabular}{|c|l|c|c|c|}
\hline Rank & Country & $\varphi$ & $\varphi+$ & $\varphi-$ \\
\hline 1 & hh & 0.8125 & 0.9018 & 0.0893 \\
\hline 2 & Germany & 0.6964 & 0.8393 & 0.1429 \\
\hline 3 & France & 0.6339 & 0.8125 & 0.1786 \\
\hline 4 & Hungary & 0.4018 & 0.6964 & 0.2946 \\
\hline 5 & Czech Republic & 0.3393 & 0.6696 & 0.3304 \\
\hline 6 & Slovakia & 0.2232 & 0.6071 & 0.3839 \\
\hline 7 & Slovenia & 0.1786 & 0.5804 & 0.4018 \\
\hline 8 & Poland & 0.1339 & 0.5536 & 0.4196 \\
\hline 9 & Bulgaria & -0.0536 & 0.4643 & 0.5179 \\
\hline 10 & Serbia & -0.0893 & 0.4464 & 0.5357 \\
\hline 11 & Montenegro & -0.1964 & 0.4018 & 0.5982 \\
\hline 12 & Croatia & -0.3661 & 0.3036 & 0.6696 \\
\hline 13 & FYR Macedonia & -0.4375 & 0.2768 & 0.7143 \\
\hline 14 & Moldova & -0.4821 & 0.2500 & 0.7321 \\
\hline 15 & Romania & -0.5179 & 0.2411 & 0.7589 \\
\hline 16 & Bosnia and & -0.6161 & 0.1875 & 0.8036 \\
\hline 17 & Herzegovina & -0.6607 & 0.1696 & 0.8304 \\
\hline
\end{tabular}

Source: The authors' calculations on the basis of World Bank and FAOstat, 2017 
All other countries had net preferences flow smaller than zero. Good ranking of Serbia can be explained by export performances of this country, especially positive export/ import coverage that is consequences of trade agreements of Serbia with the EU, CEFTA countries and EFTA (Switzerland, Norway, Iceland and Liechtenstein) as well as with Russia, Belarus, Kazakhstan and Turkey. The dominant export market for agricultural products from Serbia is the EU market, where last year exported more than $50 \%$ of agricultural products. The second most important market of the region is the market of CEFTA agreement. This structure of exports indicates that the most important markets for Serbia are EU and CEFTA (Ristić and Obradović, 2015).

Figure 1. Correlation between GDP per capita and economic performances of agriculture

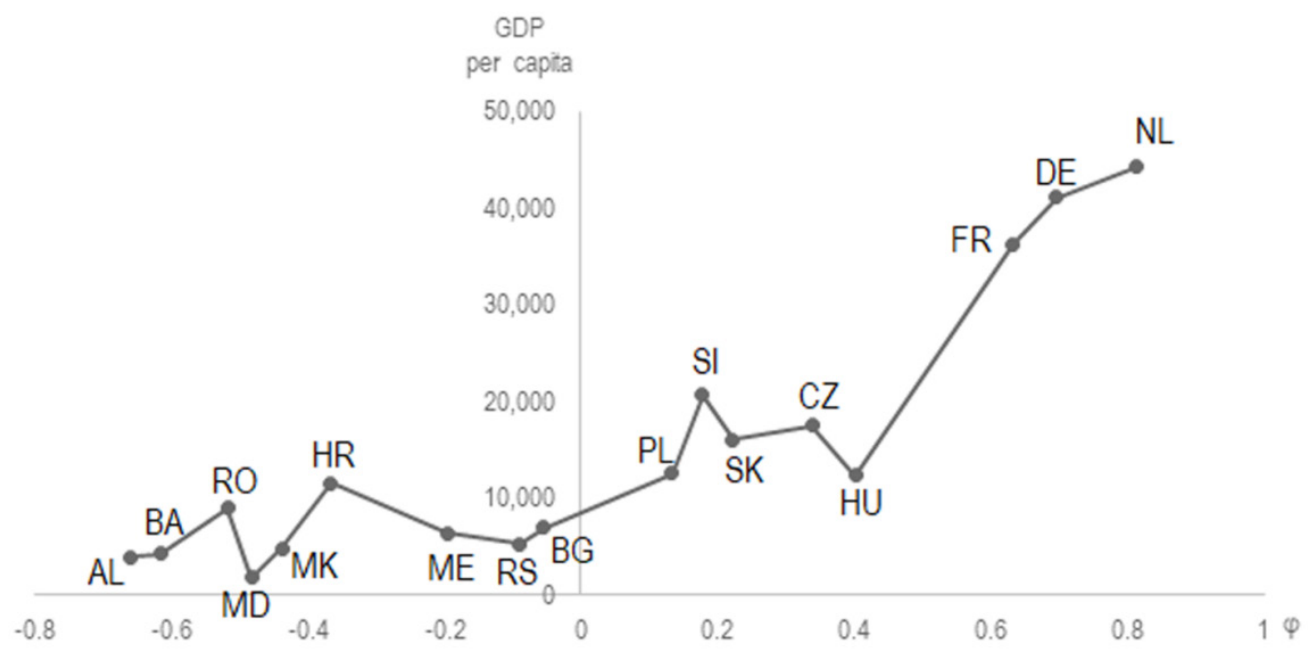

Source: The authors' calculations on the basis of World Bank and FAOstat, 2017

It is very important to notice that there is a strong positive correlation between the levels of development (observed as GDP per capita) of selected countries and the performances of the agricultural sector (Coefficient of correlation is 0.87 ). Therefore, it is possible to conclude that among other factors, the level of economic development has a significant impact on economic performance of agriculture (Figure 1).

\section{Conclusion}

The study assesses the economic performances of agriculture of current and former CEFTA. The Netherlands, Germany and France are included in analysis as a benchmark. Two clusters of selected countries were identified, differing significantly in terms of the importance of agriculture in their economy. Importance of agricultural sector is still high in Romania. Therefore, Romania is more similar to CEFTA than EU countries. On the other hand, Montenegro was placed among EU countries. In order to rank development performances of these countries, PROMETHEE method was used. Based on this analysis, countries can be roughly divided into three groups. First group consisted of 
the most developed countries that were used as a benchmark. Members of the second group are former CEFTA countries that joined EU in 2004. All other countries are members of the third group. The study showed that there is a gap in development of agriculture between CEFTA countries and selected EU countries. Among EU countries, Bulgaria, Croatia and Romania have the least developed agricultural sector. It can be assumed that effects of EU accession have yet to become visible. On the other hand in CEFTA countries performances of agricultural sector are far from EU. Among these countries, the best ranking has Serbia, and agricultural sector in Albania is the least developed. With respect to all limitations of the study related to definition of economic performances of agriculture, conclusions can be summarized as follows:

- Empirical analyses of agriculture in the CEFTA and selected EU countries indicate a large differentiation between these countries. Among other factors, the level of economic development has a significant impact on economic performance of agriculture. So, economic development of agriculture is determined by the level of socio-economic development.

- Significant difference between production and export performances of agricultural sector of the EU and CEFTA countries indicate that there is a need for adequate instruments of agricultural policy that will improve agricultural sector in these countries before EU assessment. Agricultural policy of CEFTA countries must still be oriented on increasing of productivity of agricultural sector in order to reach out EU and to get chance to compete on EU market.

- In recent years, the EU has been faced with different economic, social and political problems. In addition to the global economic crisis and migrant crisis, the new serious problem is the decision of citizens of Great Britain to leave the EU. In these circumstances, it is unlikely that the further enlargement of the EU will be soon reached. Therefore, the position of the countries that aspiring to join the EU is not favourable. This political-economic trends are forcing these countries to find temporary alternative solutions for achieving higher economic growth. One of the possible solutions is deeper integration within the CEFTA agreement, in preparation for entry into the EU.

\section{Literature}

1. Berlage, L., Terweduwe, D. (1988): The classification of countries by cluster and by factor analysis, World Development, vol. 16, no.12, pp. 1527-1545.

2. Bielik P., Smutka L., Svatos M., Hupkova D. (2013): Czech and Slovak agricultural foreign trade-two decades after the dissolution, Agricultural, vol. 59, no. 4, pp. 441-453.

3. Brans, J. P., Mareschal, B., Vincke, P. (1984): PROMETHEE: A new family of outranking methods in multicriteria analysis (No. 2013/9305). ULB--Universite Libre de Bruxelles.

4. Brans, J. P., Vincke, P. (1985): Note-A Preference Ranking Organisation Method: The PROMETHEE Method for Multiple Criteria Decision-Making, Management science, vol. 31, no. 6, pp. 647-656.

5. CEFTA Portal. Available at cefta.int (accessed June 2017).

6. Chrastinová, Z., Burianová, V. (2009): Economic development in Slovak 
agriculture, Agricultural Economics, vol. 55, no. 2, pp. 67-76.

7. Dangerfield, M. (2006): Subregional integration and EU enlargement: Where next for CEFTA?, JCMS: Journal of Common Market Studies, vol. 44, no. 2, pp. 305-324.

8. FAO, FAOstat, Available at faostat.fao.org (accessed June 2017)

9. Gajic, M., Matkovski, B., Zekic, S., Djokic, D. (2015): Development Performances of Agriculture in the Danube Region Countries, Economics of Agriculture, vol. 62 no. 4, pp. 921.

10. Hubbard C., Luca L., Luca M., Alexandri, C. (2014): Romanian Agriculture since EU Accession: Has membership made a difference? Proceedings from the conference -142nd Seminar, May 29-30, Budapest, Hungary (No. 169794), European Association of Agricultural Economists.

11. Kikerova, I. (2009): CEFTA-2006 as Basis for Economic Reintegration of Western Balkan Countries. Proceedings from conference - the Third International Conference Regional cooperation and economic integration Challenges and Opportunities October 15th - 17th 2009, Skoplje, pp. 157-169.

12. Lattin, J. M., Carroll, J. D., Green, P. E. (2003): Analyzing multivariate data. Pacific Grove, CA: Thomson Brooks/Cole

13. Miklos, S. (2014): Hungarian Agriculture a Decade after EU Accession: Hopes, Facts and Lessons. Unia Europejska. no. 2, pp. 41-51.

14. Mizik T., Meyers W. (2013): The possible effects of the EU accession on the Western Balkans agricultural trade, Economics of Agriculture, vol. 60, no. 4, pp 857-865.

15. Nikolić, R., Fedajev, A., Stefanović, V., Ilić, S. (2017): The Agriculture Sector in Western Balkans-Some Characteristics of Development. Economics of Agriculture, vol. 64, no. 1, pp. 275-293.

16. Nowak, A., Kaminska, A. (2016): Agricultural competitiveness: The case of the European Union countries, Agricultural Economics, vol. 62, no. 11, pp. 507-516.

17. Ristić, L., Obradović, S. (2015): Opportunities and limitations on exports of agricultural products of the Republic of Serbia to the EU market. Proceedings from the conference - Economic and social aspects of Serbia joining the European Union, University of Kragujevac - Faculty of Economics, pp. 93-103.

18. Stanojević, S., Đorđević, N., Volf, D. (2017): Primena kvantitativnih metoda u predviđanju poslovanja privrednih društava, Oditor, Vol. 3, No. 1, pp. 80-90.

19. Szabo, L., Grznar, M. (2015): Agriculture in the EU and position of the Slovak Republic, Agricultural Economics, vol. 61, no. 11, pp. 493-501.

20. The World Bank. Available at data.worldbank.org (accessed June 2017).

21. Van Passel, S., Nevens, F., Mathijs, E., Van Huylenbroeck, G. (2007): Measuring farm sustainability and explaining differences in sustainable efficiency, Ecological economics, vol. 62 , no.1, pp. 149-161. 


\title{
EKONOMSKE PERFORMANSE POLJOPRIVREDE U CEFTA I BIVŠIM CEFTA ZEMLJAMA ${ }^{6}$
}

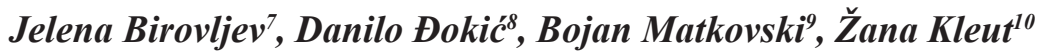

\begin{abstract}
Rezime
Sve zemlje CEFTE su se nakon II svetskog rata susrele sa veoma sličnim fazama ekonomskog razvoja. Većina ovih zemalja su bile centralno-planske socijalističke ekonomije, a političke promene sa kojim su se susrele krajem 20. veka, uticale su na promene u celokupnom ekonomskom sistemu, pa i u poljoprivrednom sektoru. Cilj ovog rada je komparativna analiza ekonomskih performansi poljoprivrede ovih zemalja i zemalja koje su ranije činile CEFTU (Poljska, Češka, Slovačka, Mađarska, Slovenija, Bugarska, Rumunija i Hrvatska), a koje su se pridružile Evropskoj uniji nakon 2014. godine. Razvojne performanse poljoprivrede su posmatrane sa stanovišta proizvodnih i izvoznih performansi ovog sektora ekonomije, koristeći komparativnu analizu. Rezultat su pokazali da postoji gep u razvoju poljoprivrede između CEFTA zemalja i selektovanih zemalja EU, a performanse poljoprivrednog sektora ovih zemalja su daleko od EU.
\end{abstract}

Ključne reči: Poljoprivreda, Promethee metod, Klaster analiza, EU, CEFTA.

JEL: $Q 17, Q 18, F 15$

6 Rad predstavlja deo istraživanja na projektu: Održiva poljoprivreda i ruralni razvoj u funkciji ostvarivanja strateških ciljeva Republike Srbije u okviru Dunavskog regiona (III 46006), finansiran od strane Ministarstva prosvete, nauke i tehnološkog razvoja Republike Srbije.

7 Redovni profesor dr Jelena Birovljev, Univerzitet u Novom Sadu, Ekonomski fakultet u Subotici, Segedinsku put 9-11, 24000 Subotica, Srbija, Telefon: +38124628066, E-mail: birovljevj@ef.uns.ac.rs

8 Danilo Đokić, asistent, Univerzitet u Novom Sadu, Ekonomski fakultet u Subotici, Segedinsku put 9-11, 24000 Subotica, Srbija, Telefon: +381214852907, E-mail: danilo. djokic@ef.uns.ac.rs

9 Bojan Matkovski, asistent, Univerzitet u Novom Sadu, Ekonomski fakultet u Subotici, Segedinsku put 9-11, 24000 Subotica, Srbija, Telefon: +38124628046, E-mail: bojan. matkovski@ef.uns.ac.rs

10 Žana Kleut, asistent, Univerzitet u Novom Sadu, Ekonomski fakultet u Subotici, Segedinsku put 9-11, 24000 Subotica, Srbija, Telefon: +381214852907, E-mail:zana.kleut@ef.uns.ac.rs 
ECONOMICS OF

AGRICULTURE

\section{CONTENT}

1. Adriana Radosavac, Desimir Knežević

ECONOMIC IMPORTANCE OF USE

OF PESTICIDES IN WHEAT PRODUCTION . . . . . . . . . . . 1323

2. Berhe Gebregewergs, Muuz Hadush

DOES CLIMATE CHANGE AFFECT PRICE OF VEGETABLES:

EVIDENCE FROM TIGRAI, NORTHERN MOST ETHIOPIA. . . . .1335

3. Grujica Vico, Aleksandra Govedarica-Lučić, Zoran Rajić, Radomir Bodiroga, Ivan Mičić, Silvija Zec Sambol, Marija Mičić

MULTI ATTRIBUTE ASSESSMENT APPROACH

IN VEGETABLE PRODUCTION . . . . . . . . . . . . . . 1355

4. Igor Trandafilović, Vesna Conić, Aleksandra Blagojević

IMPACT OF DEMOGRAPHIC FACTORS ON

ENVIRONMENTALLY CONSCIOUS PURCHASE BEHAVIOUR. . .1365

5. Imre Milán Harcsa

STUDY ON THE POTENTIAL OF SUBCONTRACT

PALINKA DISTILLATION . . . . . . . . . . . . . . 1379

6. Jelena Andrašić, Vera Mirović, Nada Milenković, Branimir Kalaš, Miloš Pjanić

IMPACT OF TAKEOVER PROCESS ON EMPLOYEES -

EVIDENCE FROM FOOD, RETAIL AND FINANCIAL SECTOR . . .1393

7. Jelena Birovljev, Danilo Đokić, Bojan Matkovski, Žana Kleut

ECONOMIC PERFORMANCES OF AGRICULTURE

OF CEFTA AND FORMER CEFTA COUNTRIES . . . . . . . . . . 1413

8. Jelena Marković, Svetlana Stevović

SUSTAINABILITY OF CHEMICAL SOIL QUALITY

IN SOUTHERN MORAVA RIVER VALLEY

IN CORELLATION WITH THE FLOODING $\ldots \ldots \ldots \ldots \ldots$ 
9. Mile Peševski, Zoran Milovančević

THE CHANGES IN THE USAGE OF AGRICULTURAL LAND

IN EASTERN REGION OF REPUBLIC OF MACEDONIA

BETWEEN $1991-2030 \ldots \ldots$. . . . . . . . . . . . . . . . . . . . . . .

10. Odjuvwuederhie Emmanuel Inoni, 'Oraye Dicta Ogisi, Felix Odemero Achoja

PROFITABILITY AND TECHNICAL EFFICIENCY IN HOMESTEAD

CATFISH PRODUCTION IN DELTA STATE, NIGERIA . . . . . . . 1449

11. Olja Munitlak - Ivanović, Jovan Zubović, Petar Mitić

RELATIONSHIP BETWEEN SUSTAINABLE DEVELOPMENT AND

GREEN ECONOMY - EMPHASIS ON GREEN FINANCE

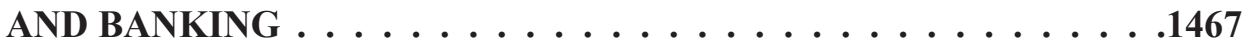

12. Petar Munćan, Dragica Božić

FARM SIZE AS A FACTOR OF EMLOYMENT AND INCOME

OF MEMBERS OF FAMILY FARMS . . . . . . . . . . . . . 1483

13. Rade Popović, Mira Kovljenić

EFFICIENCY OF WHEAT PRODUCTION ON FARMS

IN THE REPUBLIC OF SERBIA . . . . . . . . . . . . . . . . . . . . . . . . .

14. Radovan Damnjanović, Snežana Krstić, Milena Knežević, Svetislav Stanković,

Dejan Jeremić

THE DISCRIMINANT ANALYSIS APPLIED TO THE

DIFFERENTIATION OF SOIL TYPES . . . . . . . . . . . . 1513

15. Slavica Otović, Dunja Demirović, Kristina Košić, Aleksandra Vujko

FOSTERING ENTERPRENUERSHIP AT HIGH SCHOOLS:

A CASE OF RURAL AREAS IN VOJVODINA (SERBIA) . . . . . . .1523

16. Vladimir Ilić, Ivan Bauer, Anastazija Tanja Đelić, Aleksandar Nešković

INSTITUTIONAL SUPPORT FOR STRENGTHENING

ENTREPRENEURSHIP IN AGRICULTURAL PRODUCTION

OF THE REPUBLIC OF SERBIA . . . . . . . . . . . . . . . . . . . . . . . .

17. Boro Krstić, Zorica Vasiljević, Miroslav Nedeljković

INSURANCE CONTRACT AS THE BASIS FOR THE SAFETY OF

AGRICULTURAL PRODUCERS IN THE REPUBLIC OF SRPSKA • . 1555

18. Dejan Sekulić, Aleksandar Petrović, Vladimir Dimitrijević

WHO ARE WINE TOURISTS? AN EMPIRICAL INVESTIGATION

OF SEGMENTS IN SERBIAN WINE TOURISM . . . . . . . . . . . . . 
19. Milan Beslać, Ćorić Goran

FINANCIAL AND PRODUCTION ASPECTS OF GENETICALLY MODIFIED ORGANISMS $\ldots \ldots \ldots \ldots \ldots \ldots \ldots \ldots \ldots$

20. Mlađan Maksimović, Darjan Karabašević, Miodrag Brzaković, Pavle Brzaković THE EFFECTS RESULTING FROM THE APPLICATION OF THE CONCEPT OF THE SUSTAINABLE DEVELOPMENT OF RURAL TOURISM ON STARA PLANINA . . . . . . . . . . . . . . . .1595

21. Vesna Popović, Predrag Vuković, Milivoje Ćosić FOOD SAFETY AND QUALITY POLICY IN THE REPUBLIC OF SERBIA . . . . . . . . . . . . . . . . 1607

22. Radovan Pejanović, Danica Glavaš-Trbić, Mirela Tomaš-Simin PROBLEMS OF AGRICULTURAL AND RURAL DEVELOPMENT IN SERBIA AND NECESSITY OF NEW AGRICULTURAL POLICY . . . .1619

23. Saša Marković, Slavoljub Vujović, Aleksandar Damnjanović MARKETING AND HIGHER EDUCATION CONDITION IN SERBIA . . . . . . . . . . . . . . . . 1635

24. Semir Vehapi, Marina Milanović THE EFFECT OF MARKET ORIENTATION ON BUSINESS PERFORMANCE OF SERBIAN ORGANIC PRODUCERS . . . . . 1651

25. Suad Bećirović, Šemsudin Plojović, Enis Ujkanović, Senadin Plojović CHALLENGES AT STARTING AN AGRIBUSINESS IN THE HILLY MOUNTAINOUS REGIONS OF SOUTHWEST SERBIA . . . . . . . .1669

26. Vladimir Zakić, Vlado Kovačević, Jelena Damnjanović SIGNIFICANCE OF FINACIAL LITERACY FOR THE AGRICULTURAL HOLDINGS IN SERBIA . . . . . . . . . . 1687

27. Željko Bjelajac, Marijana Dukić Mijatović, Željko Vojinović PROTECTION OF LAND IN THE REPUBLIC OF SERBIA AND ECOLOGICAL SECURITY WITH REGARD TO STRATEGIC AND LEGAL FRAMEWORKS . . . . . . . . . .1703 